\title{
An Evaluation Study of Different White Rot Fungi for Degradation of Pine Needles under Solid State Fermentation
}

\author{
Nivedita Sharma*, Nisha Sharma and Dimple
}

Microbiology Research laboratory, Department of Basic sciences, Dr. Y.S. Parmar University of Horticulture and Forestry, Nauni (Solan) Himachal Pradesh 173230, India

*Corresponding author

\section{A B S T R A C T}

\section{Keywords}

Cellulase, Xylanase, Laccase, Solid state fermentation, Pine needles

Article Info

Accepted:

07 May 2019

Available Online:

10 June 2019
The present study was focused on the biodegradation of pine needles by the production of hydrolytic enzymes viz. cellulase, xylanase, laccase as well as reducing sugars production w.r.t optimization of moisture (Basal salt media) ratio for the newly isolated white rot fungi Phanerochaete sp. S7, Armillaria sp. K3 and Phanerochaete chrysosporium [NCIM 1197] were optimized under solid state fermentation and maximum of cellulase (52.27 $\mathrm{U} / \mathrm{g}$ ) with specific activity of 2.10 was observed in $P$. chrysosporium using untreated pine needles as substrate at 1:4 of moisture ratio, while maximum of xylanase and laccase were expressed by white rot Armillaria sp K3 at 1:4 of moistening agent i.e.174.00 U/g and $5.94 \mathrm{U} / \mathrm{g}$ with respect to their specific activities of 7.65 and 0.28 using untreated pine needles. In case of reducing sugars maximum of $15.48 \mathrm{mg} / \mathrm{g}$ was released at 1:4 of moisture using pretreated pine needles which is followed by the value of $14.88 \mathrm{mg} / \mathrm{g}$ at $1: 3$ by $P$. chrysosporium in untreated pine needles. In our study the newly isolated white rot fungi Phanerochaete sp. S7 and Armillaria sp. K3 were found to be potential strains for the hyper production of lignin degrading enzyme i.e. laccase as compared to the standard strain Phanerochaete chrysosporium [NCIM 1197].

\section{Introduction}

Nowadays, the fossil fuel shortage and environmental pollution are two main challenges, which need to be addressed by our society (Sharma and Sharma, 2018). The growing populations, rapid increase in industrialization, modernization of agricultural, house hold practices as well as transportation have tremendous impact on our environment and this also increased the demand for energy especially for liquid fuel.
Production of fuels, especially bio-ethanol from lignocellulosic biomass, holds remarkable potential to meet the current energy demand as well as to mitigate greenhouse gas emissions for a sustainable clean environment (Sharma et al., 2019). The lignocellulosic biomass comprises of cellulose, hemicellulose and lignin which have the great potential for the production of industrially important enzymes cellulase and xylanases under solid sate fermentation (Sharma and Sharma, 2017 a). Among 
lignocellulosic biomass, pine needles have the vast potential to be used as the substrate for biodegradation which serves as the best source for second generation biofuel production (Sharma and Sharma, 2018). Chir pine scientifically known as Pinus roxburghii (family Coniferae) is one of the six pines of India and the most widely occurring, also known as long needles pine, long leaved Indian pine. Himachal Pradesh is home for a massive number of pine trees. During monsoon, the pine trees shed leaves which end up covering the lands within the forest and reduce the fertility of soil. The mound of needles also catch fire and becomes highly combustible, after it gets dry. With people residing in the area also burning waste, the dry pine cones and the burnt garbage can lead to a forest fire, thereby destroying most of the forest. So it is very interesting to use this forest waste for bioethanol production and for its complete degradation there is a need of potential hydrolytic enzymes/ microorganisms which make it more accessible for hydrolysis into simpler sugars.

Enzymes of industrial interest are routinely being used for various processes to satisfy the needs of both the manufacturer and the end user (Panda et al., 2012, Sohail et al., 2009). Microbes serve as a potential producer a variety of enzymes that have been successfully used on industrial level (Dalvi and Anthappan, 2007). Microbial enzymes have found their applications in biofuel, textile, detergents, paper and pulp, food as well as leather industries (Akpan, 2004). In recent years, the potentials of using fungi as biotechnological sources of industriallyrelevant enzymes have stimulated interest in the exploration of extracellular enzyme producing microbes (Pathania, 2018). Fungi are of great interest as a source of multiple carbohydrases due to their easy cultivation and high production of enzymes. Most of the fungi i.e. Aspergillus spp., Fusarium spp.,
Penicillium spp. are important producers of xylanase due to high yields and extracellular release of the enzymes (Sharma and Sharma, 2017b). Xylanases (E.C.3.2.1.8) are the key enzymes, which play an important role in the breakdown of xylan and most commonly used for biopulping and biobleaching processes in industries (Sharma and Sharma, 2016). Trichoderma harzianum is also reported as the best producer of hydrolytic enzymes (Ratan et al., 2018).

Therefore, there is an urgent need for developing a viable technology that can utilize pine needles as a substrate for production of bioethanol. The ability of certain microorganisms to produce multiple enzymes such as cellulase, hemicellulases and laccase can be used to generate resources for a greener and cleaner process that can produce simple sugars (pentoses and hexoses) from a readily available and cheap biomass source i.e. pine needles. Solid state fermentation is an attractive method for multiple enzyme production, especially for fungal cultivations, because of its high productivity per reactor volume and its cost effective nature. The physical support and the energy required for the growth of fungus and desirable metabolite production is primarily provided by the substrate and also for reducing the cost of enzyme, selection of cheap and easily available substrate appears to be essential. Therefore it's important to select a desirable substrate for solid state fermentation. The hyphae of the fungi support to the filamentous to penetrate into the solid substrates and simplifying the structure of substrate. The hydrolytic enzymes are excreted outside the hyphae that makes the action of hydrolytic enzymes very efficient. Penetration increases the accessibility of all available nutrients within particles. The present study describes the production of multiple hydrolytic enzymes and further optimization of moisture ratio for enhancing 
enzymes production under solid state fermentation.

\section{Materials and Methods}

\section{Collection of Biomass}

Pine needles were collected from the forests of adjoining Himalayas and brought to the laboratory. Biomass was washed with tap water and dried at $60^{\circ} \mathrm{C}$ temperature in the oven. Dried biomass was chopped into small pieces and then grinded into $2 \mathrm{~mm}$ sieve size and stored for the further experiments.

\section{Pretreatment}

Pine needles were used as the substrate and were pretreated with microwave irradiation dose at $600 \mathrm{~W}$ for 3 minutes to make it more accessible for hydrolysis.

Biodegradation of pine needles by different white rots under solid state fermentation

\section{White rots used}

Armillaria sp. K3: The strain was isolated form degraded pine wood samples collected from Kumarhatti forest, district SolanHimachal Pradesh.

Phanerochaete sp. S7: The strain was isolated form degraded pine wood samples collected from Sultanpur forest, district SolanHimachal Pradesh.

These two hyper laccase producer were isolated in our Microbiology research laboratory and identified as Armillaria sp. K3 and Phanerochaete sp. S7 on the basis of their morphological and phenotypic characteristics.

Phanerochaete chrysosporium [1197]: A standard strain procured from NCIM-National chemical laboratory-Pune, India.

\section{Biodegradation of pine needles}

To $5 \mathrm{~g}$ of each untreated and microwave pretreated pine needles, moistening agent viz. Basal salt medium was added in the different ratios of 1:2, 1:3, 1:4, 1:5 and 1:6 i.e., substrate: moistening agent) in $250 \mathrm{ml}$ Erlenmeyer flask and autoclaved. After autoclaving, the flasks were inoculated with $1 \times 10^{7}$ spores $/ \mathrm{ml}$ of white rot Phanerochaete sp. S5, Armillaria sp. K3 and Phanerochaete chrysosporium and incubated at $28^{\circ} \mathrm{C}$ for 7 days under static phase. Hydrolytic enzymes i.e. cellulase, xylanase and laccase produced during degradation as well as reducing sugars and proteins in tern were estimated as given below.

Extraction of cellulase xylanase enzyme by Repeated Extraction method (Bollag \& Edelstein, 1993)

To $5 \mathrm{~g}$ of each untreated and microwave pretreated pine needles, $50 \mathrm{ml}$ of sodium citrate buffer $(0.1 \mathrm{M}, \mathrm{pH} 6.9)$ was added and the contents were kept in the shaker for $1 \mathrm{~h}$ at $120 \mathrm{rpm}$ and then filtered through muslin cloth. The process was repeated twice with 50 $\mathrm{ml}$ of sodium citrate buffer. After filtration, contents were centrifuged at $10,000 \mathrm{rpm}$ for $20 \mathrm{~min}$ at $4^{\circ} \mathrm{C}$. The supernatant was collected and enzyme assays were performed.

\section{Enzyme assays}

\section{Cellulase assays}

Carboxy methyl cellulase, Filter Paperase and $\beta$-glucosidase assays was determined as described by Grazek (1987) and (Berghem and Petterson, 1973) using 1\% CMC, $50 \mathrm{mg}$ filter paper strips and $1 \mathrm{mM} \rho$-nitrophenyl $\beta$ D-glucopyranoside as substrate respectively. The released reducing sugars were quantified using glucose and $\rho$-nitrophenol standard curves as a reference. One unit of enzyme 
activity was defined as the amount of enzyme required to produce $1 \mu \mathrm{mol}$ of glucose $/ \rho$ nitrophenyl $\beta$-D-glucopyranoside released per min under assay conditions.

\section{Xylanase assay}

xylanase activity was determined using 1\% (w/v) oat spelt xylan in $0.055 \mathrm{mM}$ sodium acetate buffer $\mathrm{pH} 4.0$ as substrate (Miller, 1959). The released reducing sugars were quantified using a xylose standard curve as a reference. One unit of enzyme activity was defined as the amount of enzyme required to produce $1 \mu \mathrm{mol}$ of xylose per min under assay conditions.

\section{Laccase assay}

Laccase was determined as described by Rehan et al., (2016) using $2 \mathrm{mM}$ guaicol and $10 \mathrm{mM}$ sodium acetate buffer. To the $1.0 \mathrm{ml}$ of enzyme supernatant, $2.0 \mathrm{ml}$ of $10 \mathrm{mM}$ sodium acetate buffer and $1.0 \mathrm{ml}$ of $2 \mathrm{mM}$ guaicol was added and incubated at $35^{\circ} \mathrm{C}$ temperature for 15 minutes. Absorbance of reaction mixture was read at $450 \mathrm{~nm}$ against a reagent blank (Rehan et al., 2016).

\section{Protein assays}

To $0.1 \mathrm{ml}$ of culture supernatant, $2.5 \mathrm{ml}$ of Lowry's alkaline reagent was added, mixed and allowed to stand for $10 \mathrm{~min}$. Diluted (1N) Folin Ciocalteau's reagent $(0.25 \mathrm{ml})$ was added. The contents were shaken quickly and allowed to stand for $30 \mathrm{~min}$ for maximum colour development. Absorbance of reaction mixture was read at $670 \mathrm{~nm}$ against a reagent blank. The contents of protein in culture supernatant were estimated from standard curve which was prepared by using Bovine Serum Albumin (BSA) in concentration of 10-100 $\mu \mathrm{g} / \mathrm{ml}$ (Lowry et al., 1951).

\section{Reducing sugars produced}

To the $1.0 \mathrm{ml}$ of culture supernatant, $3 \mathrm{ml}$ of
Dinitrosalicylic acid (DNSA) reagent was added and the mixture was boiled in boiling water bath for 10 minutes. Absorbance of the reaction mixture was read at $540 \mathrm{~nm}$ against a reagent blank (Miller, 1959).

\section{Biodegradation index (Sharma et al, 1996)}

The biodegradation index of lignocellulosic biomass were calculated on dry matter basis by the formula:

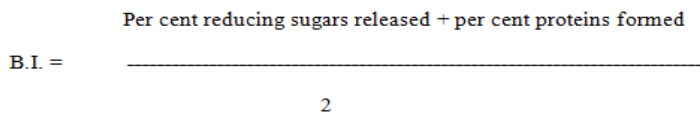

\section{Results and Discussion}

Pine needles are a difficult forest waste. They cannot serve as fodder. They do not even decay like the other biomass and piled up pine needles are a major cause of wild forest fires. They are however, a good source of biomass fuel. Though lignocellulosic biomass is a potential source of carbohydrate polymers for fermentation into simple sugars and subsequently to biofuel, saccharification of its structural polysaccharides into simple sugars is highly challenging due to its intrinsic recalcitrant nature of the lignocellulosic plant matter. It has been established that with increase in extracellular cellulase and xylanase production from hydrolytic microorganisms, biodegradation of pine needles increases. As the major impediments to exploit the commercial potential of hydrolytic enzymes (cellulase, xylanase and laccase) are the cost of their production and yield stability. One effective approach to reduce the cost of enzyme production is to replace conventional carbon source i.e. pure cellulose and xylan by relatively cheaper substrates such as lignocellulosic forest waste i.e. pine needles. Thus keeping in view the above facts, cost effective production of cellulase, xylanase and laccase by optimizing moisture ratio under solid state fermentation 
for the selected fungi white rot Armillaria sp. K3, Phanerochaete sp. S7 and $P$. chrysosporium using untreated/ pretreated pine needles was done in the present study. white rot Armillaria sp. K3 and Phanerochaete sp. S7 were isolated from decaying pine wood samples collected from forests of Kumarhatti and Sultanpur sites of district Solan, Himachal Pradesh -India and were identified as Armillaria sp. K3 and Phanerochaete sp. S7 on the basis of their morphology and phenotypic characterization. Figures 1, 2 and 3 represent the morphology of selected fungal strains Armillaria sp. K3, Phanerochaete sp. S7 and $P$. chrysosporium respectively.

Solid substrates used were insoluble in water, therefore water will have to be absorbed onto the substrate particles, which can be used by the microorganisms for growth and metabolic activity. Water causes the swelling of the substrate and facilitates utilization of substrates by the fungus as making the substrate by providing the adequate moisture for growth of fungus. Increasing moisture level is believed to have reduced the porosity of substrate, thus limiting the oxygen transfer into the substrate. Every microorganism has a distinct water activity requirement essential for its growth in the solid state fermentation. Different ratios of (substrate: moisture) were performed by changing the amount of diluents and keeping solid ratio constant. As indicated in Tables 1, 2 and 3, the enzymes production was optimum using the Basal salt medium (BSM) which was moistened with moistening agent in the different ratio of 1:2, 1:3, 1:4, 1:5 and 1:6. Different fungus gave their hyper enzyme production at their own optimum moisture level. As data revealed in table 1 hydrolytic enzymes produced by white rot fungus Armillaria sp. K3 using untreated and pretreated pine needles and maximum of cellulase $(10.94 \mathrm{U} / \mathrm{g})$ with specific activity of 0.43 , laccase of $5.94 \mathrm{U} / \mathrm{g}$ (specific activity
0.28 ) as well as reducing sugars $8.26 \mathrm{mg} / \mathrm{g}$ were observed by using untreated pine needles, while maximum xylanase (174.00 U/g) was achieved using pretreated pine needles at moisture ratio of 1:4. On the other hand minimum of cellulase $(5.00 \mathrm{U} / \mathrm{g})$ was observed in 1:2 with its specific activity of 0.61 . So the optimum moisture ratio for the Armillaria sp. K3 was 1:4 which gave its maximum of enzyme productions. Fig 4 shows the biodegradation of pine needles by Armillaria sp K3 under solid state fermentation at different substrate: moisture levels.

In case of white rot fungi Phanerochaete sp. S7 maximum of cellulase as well as reducing sugars were achieved in 1:3 i.e. $14.29 \mathrm{U} / \mathrm{g}$ within specific activity of 0.68 and $9.51 \mathrm{mg} / \mathrm{g}$ in untreated biomass respectively (Table 2). While the hyper xylanase of $183.37 \mathrm{U} / \mathrm{g}(7.11$ specific activity) and laccase of $5.61 \mathrm{U} / \mathrm{g}$ (0.28 specific activity) were observed in 1:5 moisture ratio in untreated pine needles biomass. Whereas minimum of cellulase (7.40 $\mathrm{U} / \mathrm{g})$ was produced at 1:5, xylanase $(120 \mathrm{U} / \mathrm{g})$ in $1: 6$ and laccase $(1.36 \mathrm{U} / \mathrm{g})$ in $1: 2$ of moistening agent in pretreated biomass as the fig 5 shows the biodegradation of pine needles as well as growth of white rot Phanerochaete sp. S7.

As the table 3 depicts the results of hydrolytic enzymes produced by $P$. chrysosporium using untreated and pretreated biomass in which 1:4 moisture ratio gave the maximum cellulase (52.27 U/g within specific activity 2.10), reducing sugars $(15.48 \mathrm{mg} / \mathrm{g})$ as well as xylanase $(146.89 \mathrm{U} / \mathrm{g}$ with in specific activity 5.40), while the highest value of laccase (3.07 $\mathrm{U} / \mathrm{g}$ with specific activity 0.13 ) was observed at 1:5 moisture. $P$. chrysosporium released maximum cellulase and xylanase by using pretreated pine needles, while maximum of laccase and reducing sugars by using untreated pine needles. Minimum of cellulase 
i.e. $13.85 \mathrm{U} / \mathrm{g}$, xylanase of $124.81 \mathrm{U} / \mathrm{g}$, laccase of $2.11 \mathrm{U} / \mathrm{g}$ and reducing sugars i.e. $8.37 \mathrm{mg} / \mathrm{g}$ were recorded in 1:6, 1:2, 1:4 and 1:5 respectively. Fig 6 shows the degradation of pine needles by $P$. chrysosporium at different moisture ratio under solid state fermentation.

The overall study showed that, the maximum of cellulase $(52.27 \mathrm{U} / \mathrm{g})$ with specific activity of 2.10 was observed in $P$. chrysosporium using untreated pine needles as substrate at 1:4 of moisture ratio (Fig 7), while maximum of xylanase (Fig. 8) and laccase (Fig. 9) were expressed by white rot Armillaria sp. K3 at 1:4 of moistening agent i.e.174.00 U/g and $5.94 \mathrm{U} / \mathrm{g}$ with respect to their specific activities of 7.65 and 0.28 using untreated pine needles.

In case of reducing sugars maximum of 15.48 $\mathrm{mg} / \mathrm{g}$ was released at 1:4 of moisture using pretreated pine needles which is followed by the value of $14.88 \mathrm{mg} / \mathrm{g}$ at $1: 3$ by $P$. chrysosporium in untreated pine needles (Fig. 10). In SSF the optimal moisture content depends on the requirement of microorganisms, type of the substrate and the types of end products. The high moisture level increases the free excess liquid in the medium which ultimately decrease in growth and enzyme production.

The overall comparison between these three strains was done on the basis of their biodegradation index as shown in table $4, P$. chrysosporium and Phanerochaete sp. S7 exhibited highest biodegradation index i.e. 2.21 and 1.51 respectively at moisture level of 1:3. While Armillaria sp K3 having biodegradation index of 1.45 at $1: 4$ moisture ratio in untreated pine needles biomass. As the results clearly indicates in case of Armillaria sp K3 and Phanerochaete sp S7 that untreated biomass expressed better biodegradation than pretreated biomass, on the other hand $P$. chrysosporium exhibit good biodegradation index by using pretreated pine needles biomass. In our present study Armillaria sp K3 and Phanerochaete sp S7, newly isolated strains were found good potential to degrade lignin which is very difficult to degrade in nature and hyper laccase producer as compared to the reference strain $P$. chrysosporium.

Pine needles are basically rich in silica and phenolic compounds such as tannins, it is highly resistant to decomposition in nature. However, pine needles biomass can be converted to useful renewable fuels such as biogas, biooil, bioethanol, biodiesel etc. by the use of microorganisms having the potential to degrade it. Dutt and Kumar (2014) optimized the moisture ratio of $1: 3$ (substrate: moistening agent) for enhanced cellulase production under solid state fermentation using Aspergillus flavus (AT-2) and Aspergillus niger (AT-3).

Similarly Ghoshal et al., (2015) observed that the maximum yield of xylanase was observed when lignocellulosic agrowaste was moistened in 1:5 for 5 days of incubation. Thiribhuvanamala et al., (2017) reported the production of xylanase and laccase hydrolytic enzymes from a lignolytic polypore fungi i.e. Trametes versicolor which also showed MnP and LiP enzyme production.

Cellulases and hemicellulases were also produced by Aspergillus niger and $A$. fumigates using sorghum as substrate under solid state fermentation (Dias et al., 2018). Filamentous fungi like $A$. niger and $T$. viride were also preferred for commercially important enzyme production and biodegradation of lignocellulosic biomass because the level of the enzyme produced by these cultures were higher than those obtained from yeast and bacteria (Bakri et al., 2003). 
Table.1 Biodegradation of untreated and pretreated pine needles by white rot fungus Armillaria sp. K3 under SSF

\begin{tabular}{|c|c|c|c|c|c|c|c|c|c|c|c|c|c|}
\hline \multirow[t]{2}{*}{ Sr No. } & \multirow[b]{2}{*}{$\begin{array}{l}\text { Moisture } \\
\text { ratio }\end{array}$} & \multicolumn{6}{|c|}{ Cellulase activities } & \multirow{2}{*}{$\begin{array}{c}\text { Protein } \\
\text { (mg/g) }\end{array}$} & \multicolumn{2}{|c|}{ Xylanase activities } & \multicolumn{2}{|c|}{ Laccase activities } & \multirow{2}{*}{$\begin{array}{c}\text { Reducing } \\
\text { sugars } \\
\text { (mg/g) }\end{array}$} \\
\hline & & Biomass & $\begin{array}{c}\text { CMCase } \\
\text { activity } \\
\text { (U/g) }\end{array}$ & $\begin{array}{c}\text { FPase } \\
\text { activity } \\
\text { (U/g) }\end{array}$ & $\begin{array}{c}\beta \text {-glucosidase } \\
\text { activity }(U / g)\end{array}$ & $\begin{array}{c}\text { Total } \\
\text { cellulase } \\
(\mathrm{U} / \mathrm{g})\end{array}$ & $\begin{array}{l}\text { Specific } \\
\text { activity }\end{array}$ & & $\begin{array}{c}\text { Xylanase } \\
\text { activity } \\
\text { (U/g) }\end{array}$ & $\begin{array}{l}\text { Specific } \\
\text { activity }\end{array}$ & $\begin{array}{c}\text { Laccase } \\
\text { activity } \\
\text { (U/g) }\end{array}$ & $\begin{array}{l}\text { Specific } \\
\text { activity }\end{array}$ & \\
\hline \multirow[t]{2}{*}{1.} & \multirow[t]{2}{*}{$1: 2$} & Untreated & 3.10 & 3.33 & 0.03 & 6.46 & 0.806 & 8.01 & 157.95 & 19.71 & 2.35 & 0.29 & 3.57 \\
\hline & & Pretreated & 1.66 & 3.16 & 0.18 & 5.00 & 0.61 & 8.11 & 118.20 & 14.57 & 1.81 & 0.22 & 3.40 \\
\hline \multirow[t]{2}{*}{2.} & \multirow[t]{2}{*}{$1: 3$} & Untreated & 1.51 & 3.25 & 0.39 & 5.15 & 0.660 & 7.80 & 159.15 & 20.40 & 2.40 & 0.30 & 3.79 \\
\hline & & Pretreated & 2.94 & 3.67 & 0.30 & 6.91 & 0.86 & 7.96 & 170.85 & 21.46 & 2.22 & 0.27 & 4.66 \\
\hline \multirow[t]{2}{*}{3.} & \multirow[t]{2}{*}{$1: 4$} & Untreated & 6.06 & 3.07 & 1.81 & 10.94 & 0.525 & 20.83 & 172.80 & 8.29 & 5.94 & 0.28 & 8.26 \\
\hline & & Pretreated & 3.84 & 4.15 & 1.80 & 9.79 & 0.43 & 22.72 & 174.00 & 7.65 & 4.84 & 0.21 & 3.87 \\
\hline \multirow[t]{2}{*}{4.} & \multirow[t]{2}{*}{$1: 5$} & Untreated & 3.85 & 4.25 & 1.53 & 9.63 & 0.447 & 21.52 & 159.00 & 7.38 & 4.29 & 0.19 & 4.44 \\
\hline & & Pretreated & 2.83 & 3.66 & 1.17 & 7.66 & 0.34 & 22.45 & 157.80 & 7.02 & 4.30 & 0.19 & 3.58 \\
\hline \multirow[t]{2}{*}{5.} & \multirow[t]{2}{*}{$1: 6$} & Untreated & 2.50 & 3.37 & 1.48 & 7.35 & 0.587 & 12.51 & 149.85 & 11.97 & 3.22 & 0.25 & 7.42 \\
\hline & & Pretreated & 2.82 & 3.34 & 1.27 & 7.43 & 0.59 & 12.55 & 142.69 & 11.36 & 2.79 & 0.22 & 3.12 \\
\hline \multicolumn{3}{|c|}{ C.D0.05 } & 0.40 & 0.64 & 0.02 & 0.09 & 0.07 & 0.04 & 0.02 & 0.01 & 0.06 & 0.03 & 0.08 \\
\hline \multicolumn{3}{|c|}{ S.E. (m) } & 0.10 & 0.15 & 0.17 & 0.13 & 0.20 & 0.12 & 0.11 & 0.09 & 0.10 & 0.13 & 0.11 \\
\hline
\end{tabular}

Table.2 Biodegradation of untreated and pretreated pine needles by white rot Phanerochaete sp. S7 under SSF

\begin{tabular}{|c|c|c|c|c|c|c|c|c|c|c|c|c|c|}
\hline \multirow[t]{2}{*}{ Sr No. } & \multicolumn{7}{|c|}{ Cellulase activities } & \multirow{2}{*}{$\begin{array}{c}\text { Protein } \\
(\mathrm{mg} / \mathrm{g})\end{array}$} & \multicolumn{2}{|c|}{ Xylanase activities } & \multicolumn{2}{|c|}{ Laccase activities } & \multirow{2}{*}{$\begin{array}{c}\text { Reducing } \\
\text { Sugars } \\
(\mathrm{mg} / \mathrm{g})\end{array}$} \\
\hline & $\begin{array}{l}\text { Moisture } \\
\text { ratio }\end{array}$ & Biomass & $\begin{array}{c}\text { CMCase } \\
\text { activity } \\
\text { (U/g) }\end{array}$ & $\begin{array}{c}\text { FPase } \\
\text { activity } \\
(\mathbf{U} / \mathbf{g})\end{array}$ & $\begin{array}{c}\beta- \\
\text { glucosidase } \\
\operatorname{activity}(\mathbf{U} / \mathrm{g})\end{array}$ & $\begin{array}{c}\text { Total } \\
\text { cellulase } \\
(\mathrm{U} / \mathrm{g})\end{array}$ & $\begin{array}{l}\text { Specific } \\
\text { activity }\end{array}$ & & $\begin{array}{c}\text { Xylanase } \\
\text { activity } \\
\text { (U/g) }\end{array}$ & $\begin{array}{l}\text { Specific } \\
\text { activity }\end{array}$ & $\begin{array}{l}\text { Laccase } \\
\text { activity } \\
\text { (U/g) }\end{array}$ & $\begin{array}{l}\text { Specific } \\
\text { activity }\end{array}$ & \\
\hline \multirow[t]{2}{*}{1.} & \multirow[t]{2}{*}{$1: 2$} & Untreated & 6.72 & 5.26 & 0.67 & 12.65 & 0.65 & 19.20 & 122.19 & 6.36 & 3.19 & 0.16 & 7.46 \\
\hline & & Pretreated & 5.04 & 3.24 & 0.720 & 9.00 & 0.53 & 16.95 & 123.66 & 6.19 & 1.36 & 0.08 & 5.85 \\
\hline \multirow[t]{2}{*}{2.} & \multirow[t]{2}{*}{$1: 3$} & Untreated & 7.20 & 5.56 & 1.53 & 14.29 & 0.68 & 20.83 & 126.81 & 6.08 & 3.22 & 0.15 & 9.51 \\
\hline & & Pretreated & 6.01 & 3.79 & 1.050 & 10.85 & 0.51 & 20.92 & 132.18 & 6.31 & 2.22 & 0.10 & 7.00 \\
\hline \multirow[t]{2}{*}{3.} & \multirow[t]{2}{*}{$1: 4$} & Untreated & 4.20 & 4.08 & 1.84 & 10.12 & 0.47 & 21.51 & 136.38 & 6.34 & 3.97 & 0.18 & 5.13 \\
\hline & & Pretreated & 3.75 & 3.66 & 1.755 & 9.16 & 0.44 & 20.79 & 135.85 & 6.53 & 4.42 & 0.21 & 4.56 \\
\hline \multirow[t]{2}{*}{4.} & \multirow[t]{2}{*}{$1: 5$} & Untreated & 5.04 & 4.75 & 1.78 & 11.57 & 0.59 & 19.44 & 138.37 & 7.11 & 5.61 & 0.28 & 8.28 \\
\hline & & Pretreated & 2.71 & 3.15 & 1.540 & 7.40 & 0.62 & 11.83 & 136.35 & 11.52 & 5.50 & 0.46 & 5.98 \\
\hline \multirow[t]{2}{*}{5.} & \multirow[t]{2}{*}{$1: 6$} & Untreated & 2.73 & 3.79 & 1.17 & 7.69 & 0.45 & 16.92 & 121.05 & 7.15 & 4.68 & 0.27 & 5.04 \\
\hline & & Pretreated & 1.74 & 2.62 & 1.140 & 5.50 & 0.32 & 16.94 & 120.60 & 7.11 & 4.72 & 0.27 & 4.59 \\
\hline \multicolumn{3}{|c|}{ C.D0.05 } & 0.20 & 0.34 & 0.05 & 0.09 & 0.06 & 0.04 & 0.02 & 0.03 & 0.08 & 0.05 & 0.08 \\
\hline \multicolumn{3}{|c|}{ S.E. (m) } & 0.09 & 0.17 & 0.10 & 0.14 & 0.10 & 0.11 & 0.10 & 0.08 & 0.07 & 0.14 & 0.14 \\
\hline
\end{tabular}


Table.3 Biodegradation of untreated and pretreated pine needles by $P$. chrysosporium under SSF

\begin{tabular}{|c|c|c|c|c|c|c|c|c|c|c|c|c|c|}
\hline \multirow[t]{2}{*}{ Sr No. } & \multirow[b]{2}{*}{$\begin{array}{l}\text { Moisture } \\
\text { ratio }\end{array}$} & \multicolumn{6}{|c|}{ Cellulase activities } & \multirow{2}{*}{$\begin{array}{c}\text { Protein } \\
\text { (mg/g) }\end{array}$} & \multicolumn{2}{|c|}{ Xylanase activities } & \multicolumn{2}{|c|}{ Laccase activities } & \multirow{2}{*}{$\begin{array}{c}\text { Reducing } \\
\text { sugars } \\
\text { (mg/g) }\end{array}$} \\
\hline & & Biomass & $\begin{array}{c}\text { CMCase } \\
\text { activity } \\
\text { (U/g) }\end{array}$ & $\begin{array}{c}\text { FPase } \\
\text { activity( } \\
\text { U/g) }\end{array}$ & $\begin{array}{l}\beta \text {-glucosidase } \\
\operatorname{activity}(\mathrm{U} / \mathrm{g})\end{array}$ & $\begin{array}{c}\text { Total } \\
\text { cellulase } \\
\text { (U/g) }\end{array}$ & $\begin{array}{l}\text { Specific } \\
\text { activity }\end{array}$ & & $\begin{array}{c}\text { Xylanase } \\
\text { activity } \\
\text { (U/g) }\end{array}$ & $\begin{array}{l}\text { Specific } \\
\text { activity }\end{array}$ & $\begin{array}{c}\text { Laccase } \\
\text { activity } \\
\text { (U/g) }\end{array}$ & $\begin{array}{l}\text { Specific } \\
\text { activity }\end{array}$ & \\
\hline \multirow[t]{2}{*}{1.} & \multirow[t]{2}{*}{$1: 2$} & Untreated & 11.19 & 12.01 & 1.78 & 24.98 & 1.09 & 22.72 & 124.81 & 5.49 & 2.47 & 0.10 & 12.12 \\
\hline & & Pretreated & 10.86 & 11.01 & 1.65 & 23.52 & 0.93 & 25.11 & 125.70 & 5.00 & 2.16 & 0.08 & 10.98 \\
\hline \multirow[t]{2}{*}{2.} & \multirow[t]{2}{*}{$1: 3$} & Untreated & 12.90 & 13.11 & 1.84 & 27.85 & 0.98 & 28.26 & 137.32 & 4.85 & 2.80 & 0.09 & 14.88 \\
\hline & & Pretreated & 5.83 & 12.52 & 1.78 & 20.13 & 0.65 & 30.51 & 132.18 & 4.33 & 2.79 & 0.09 & 13.76 \\
\hline \multirow[t]{2}{*}{3.} & \multirow[t]{2}{*}{$1: 4$} & Untreated & 38.82 & 11.56 & 1.89 & 52.27 & 2.10 & 24.88 & 141.60 & 5.69 & 2.11 & 0.08 & 14.00 \\
\hline & & Pretreated & 10.78 & 11.20 & 1.80 & 23.78 & 0.87 & 27.20 & 146.89 & 5.40 & 2.82 & 0.10 & 15.48 \\
\hline \multirow[t]{2}{*}{4.} & \multirow[t]{2}{*}{$1: 5$} & Untreated & 6.19 & 11.44 & 1.86 & 19.49 & 0.85 & 22.92 & 137.95 & 6.01 & 3.07 & 0.13 & 10.68 \\
\hline & & Pretreated & 6.42 & 10.63 & 1.80 & 18.85 & 0.81 & 23.17 & 142.69 & 6.15 & 3.02 & 0.13 & 8.37 \\
\hline \multirow[t]{2}{*}{5.} & \multirow[t]{2}{*}{$1: 6$} & Untreated & 5.79 & 10.51 & 1.53 & 17.83 & 0.91 & 19.44 & 127.86 & 6.57 & 2.41 & 0.12 & 9.96 \\
\hline & & Pretreated & 4.99 & 7.38 & 1.48 & 13.85 & 0.67 & 20.45 & 129.13 & 6.31 & 2.80 & 0.13 & 9.60 \\
\hline \multicolumn{3}{|c|}{ C.D0.05 } & 0.30 & 0.34 & 0.06 & 0.04 & 0.06 & 0.07 & 0.04 & 0.01 & 0.06 & 0.03 & 0.09 \\
\hline \multicolumn{3}{|c|}{ S.E. (m) } & 0.11 & 0.25 & 0.18 & 0.13 & 0.23 & 0.12 & 0.19 & 0.08 & 0.11 & 0.17 & 0.16 \\
\hline
\end{tabular}

Table.4 Biodegradation index (BI) of untreated and pretreated pine needles after solid state fermentation by Armillaria sp. K3, Phanerochaete sp. S7 and P. chrysosporium under SSF

\begin{tabular}{|c|c|c|c|c|c|c|c|c|c|c|c|c|}
\hline \multirow[t]{2}{*}{ Sr No. } & \multirow{2}{*}{$\begin{array}{l}\text { Moisture } \\
\text { ratio }\end{array}$} & \multirow[t]{2}{*}{ Biomass } & \multicolumn{3}{|c|}{ Armillaria sp. K3 } & \multicolumn{3}{|c|}{ Phanerochaete sp. S7 } & \multicolumn{3}{|c|}{ P. chrysosporium } & \multirow[t]{2}{*}{ Mean } \\
\hline & & & $\begin{array}{c}\text { \% Reducing } \\
\text { sugars }\end{array}$ & $\%$ proteins & B.I. & $\begin{array}{c}\text { \% Reducing } \\
\text { sugars }\end{array}$ & $\begin{array}{c}\% \\
\text { proteins }\end{array}$ & B.I. & $\begin{array}{l}\text { \% Reducing } \\
\text { sugars }\end{array}$ & $\begin{array}{c}\% \\
\text { proteins }\end{array}$ & B.I. & \\
\hline \multirow[t]{2}{*}{1.} & \multirow[t]{2}{*}{$1: 2$} & Untreated & 0.35 & 0.80 & 0.57 & 0.74 & 1.92 & 1.33 & 1.21 & 2.27 & 1.74 & 1.21 \\
\hline & & Pretreated & 0.34 & 0.81 & 0.57 & 0.58 & 1.69 & 1.13 & 1.09 & 2.51 & 1.80 & 1.16 \\
\hline \multirow[t]{2}{*}{2.} & \multirow[t]{2}{*}{$1: 3$} & Untreated & 0.37 & 0.78 & 0.57 & 0.95 & 2.08 & 1.51 & 1.48 & 2.82 & 2.15 & 1.41 \\
\hline & & Pretreated & 0.46 & 0.79 & 0.62 & 0.70 & 2.09 & 1.39 & 1.37 & 3.05 & 2.21 & 1.40 \\
\hline \multirow[t]{2}{*}{3.} & \multirow[t]{2}{*}{$1: 4$} & Untreated & 0.82 & 2.08 & 1.45 & 0.51 & 2.15 & 1.33 & 1.40 & 2.48 & 1.94 & 1.57 \\
\hline & & Pretreated & 0.38 & 2.27 & 1.32 & 0.45 & 2.07 & 1.26 & 1.54 & 2.72 & 2.13 & 1.57 \\
\hline \multirow[t]{2}{*}{4.} & \multirow[t]{2}{*}{$1: 5$} & Untreated & 0.44 & 2.15 & 1.29 & 0.82 & 1.94 & 1.38 & 1.06 & 2.29 & 1.67 & 1.44 \\
\hline & & Pretreated & 0.35 & 2.24 & 1.29 & 0.59 & 1.18 & 0.88 & 0.83 & 2.31 & 1.57 & 1.24 \\
\hline \multirow[t]{2}{*}{5.} & \multirow[t]{2}{*}{$1: 6$} & Untreated & 0.74 & 1.25 & 0.99 & 0.50 & 1.69 & 1.09 & 0.99 & 1.94 & 1.46 & 1.18 \\
\hline & & Pretreated & 0.31 & 1.25 & 0.78 & 0.45 & 1.69 & 1.07 & 0.96 & 2.04 & 1.50 & 1.11 \\
\hline
\end{tabular}


Fig.1 Morphology of white rot fungus Armillaria sp. K3

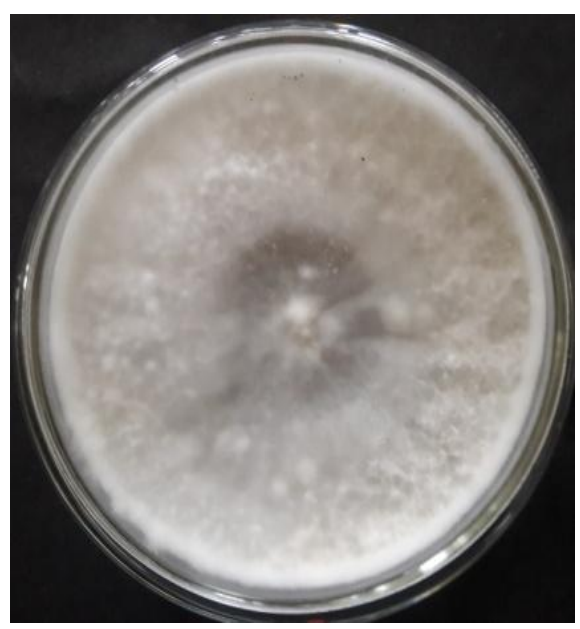

Fig.2 Morphology of white rot fungus Phanerochaete sp. S7

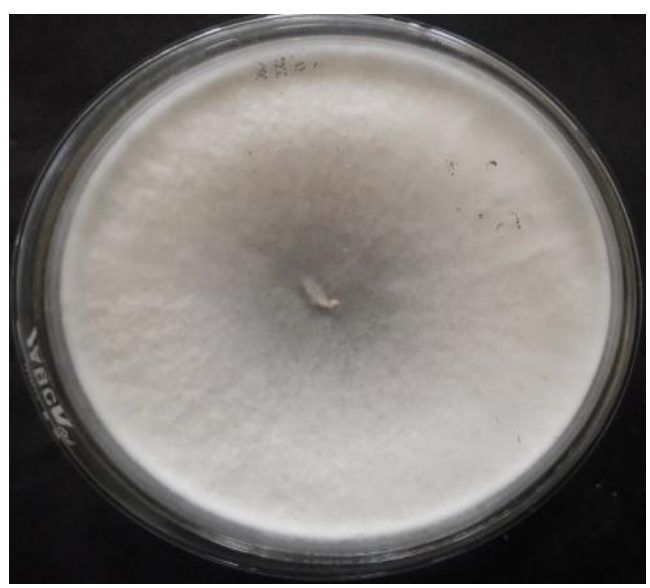

Fig.3 Morphology of $P$. chrysosporium

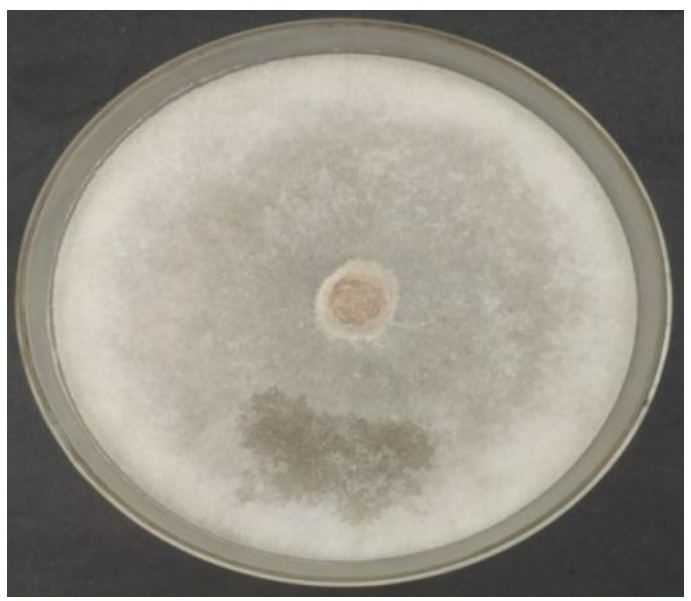


Fig.4 Solid state fermentation by white rot Armillaria sp. K3 using untreated and pretreated pine needles at moisture ratio of (a) 1:2 (b) 1:3 (c) 1:4 (d) 1:5 (e) 1:6

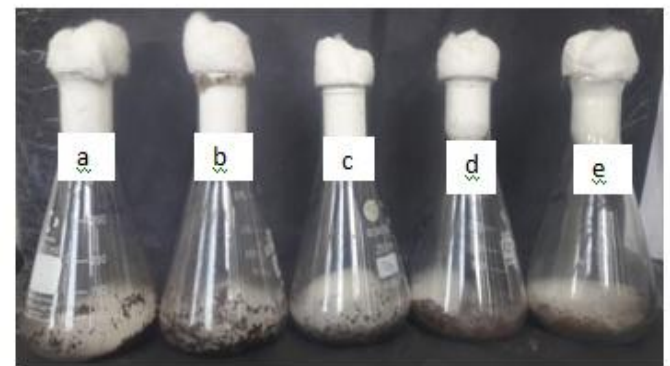

(i) Untreated

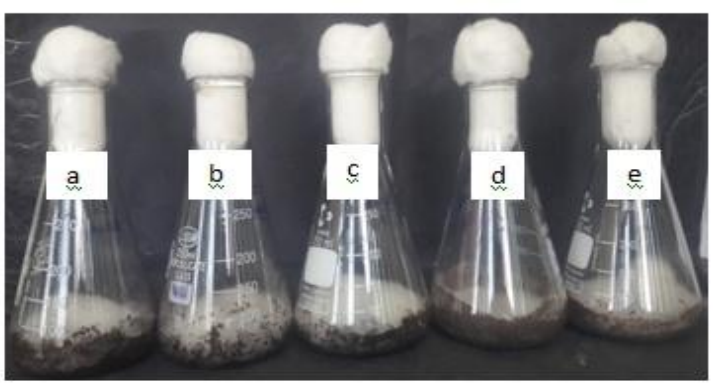

(ii) Pretreated

Fig.5 Solid state fermentation by white rot Phanerochaete sp. S7 using untreated and pretreated pine needles at moisture ratio of (a) 1:2 (b) 1:3 (c) 1:4 (d) 1:5 (e) 1:6

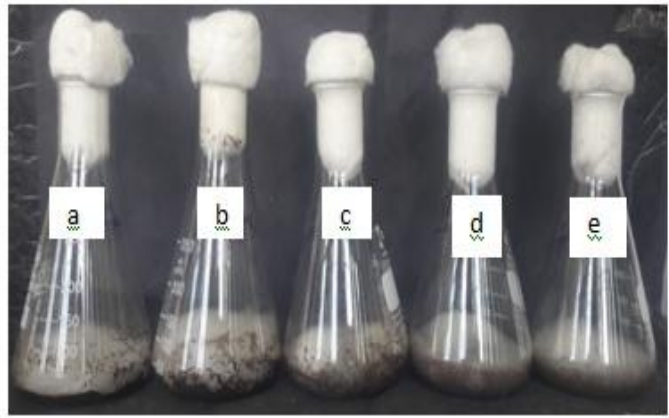

(i) Untreated

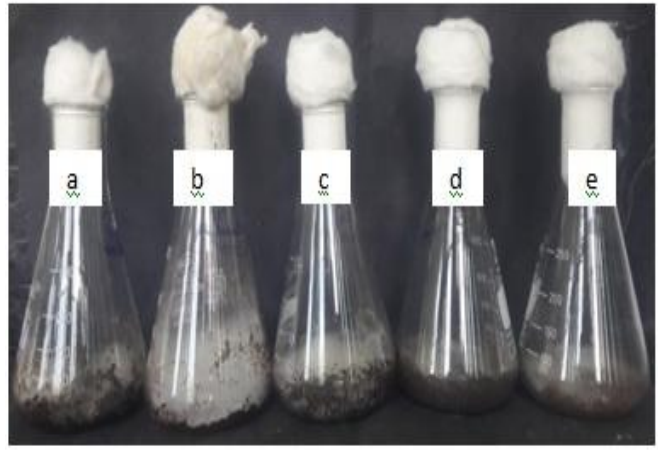

(ii) Pretreated

Fig.6 Solid state fermentation by $P$. chrysosporium using untreated and pretreated pine needles at moisture ratio of (a) 1:2 (b) 1:3 (c) 1:4 (d) 1:5 (e) 1:6

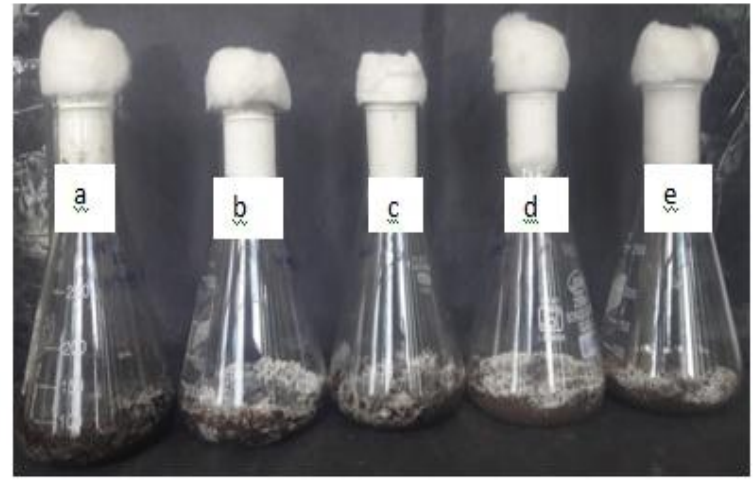

(i) Untreated

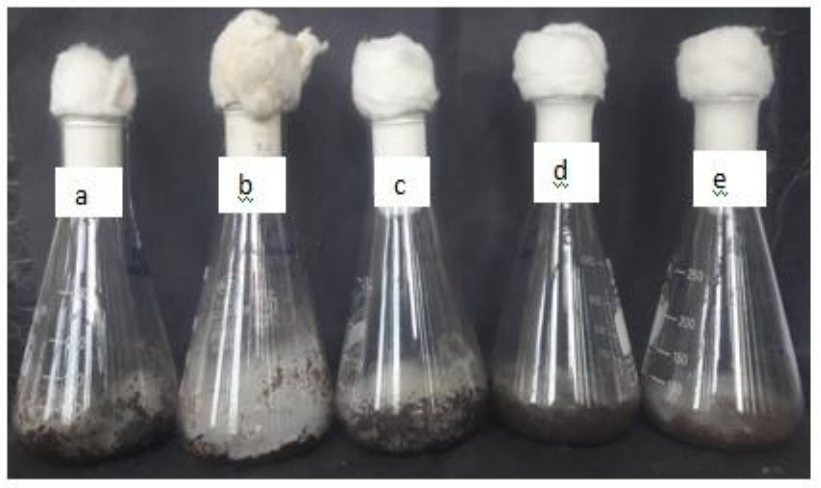

(ii) Pretreated 
Fig.7 Comparison of Cellulase production by Armillaria sp. K3, Phanerochaete sp. S7 and P. chrysosporium under SSF

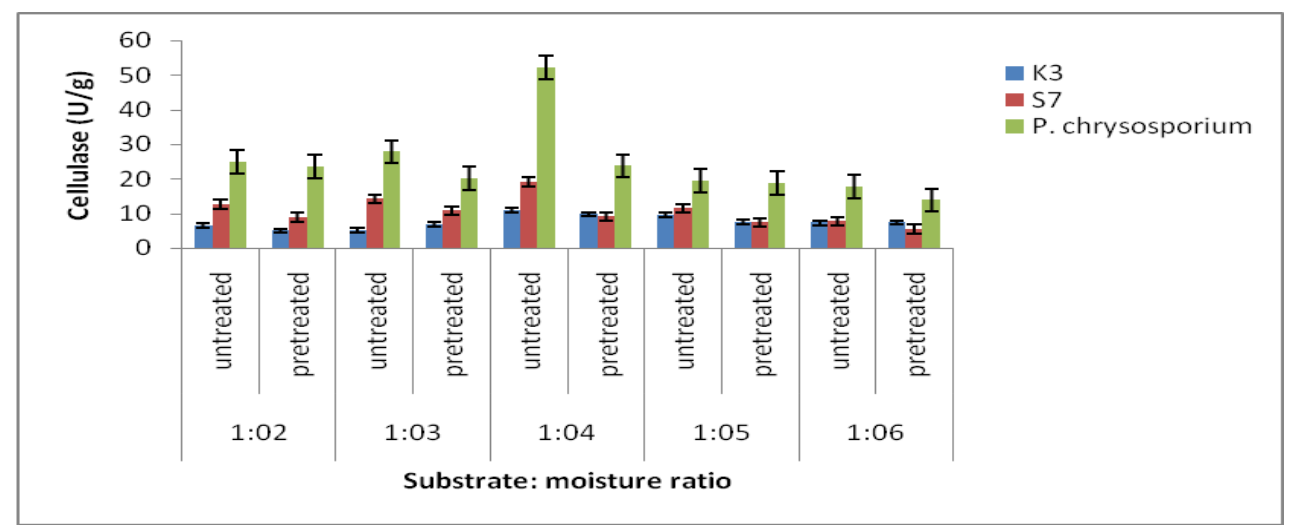

Fig.8 Comparison of xylanase production by Armillaria sp. K3, Phanerochaete sp. S7 and $P$. chrysosporium under SSF

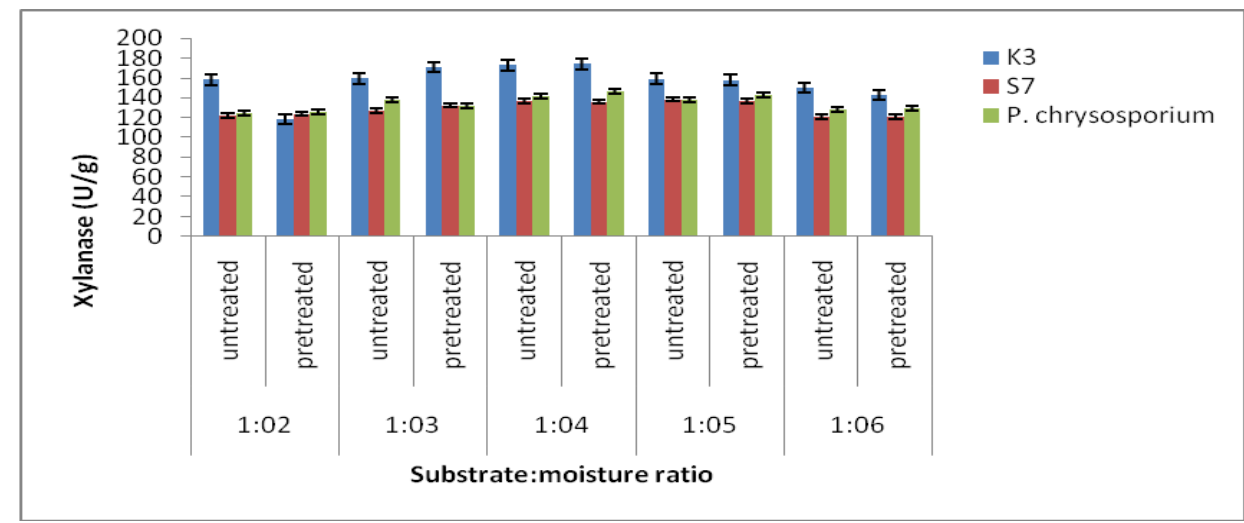

Fig.9 Comparison of reducing sugar production by Armillaria sp. K3, Phanerochaete sp. S7 and $P$. chrysosporium under SSF

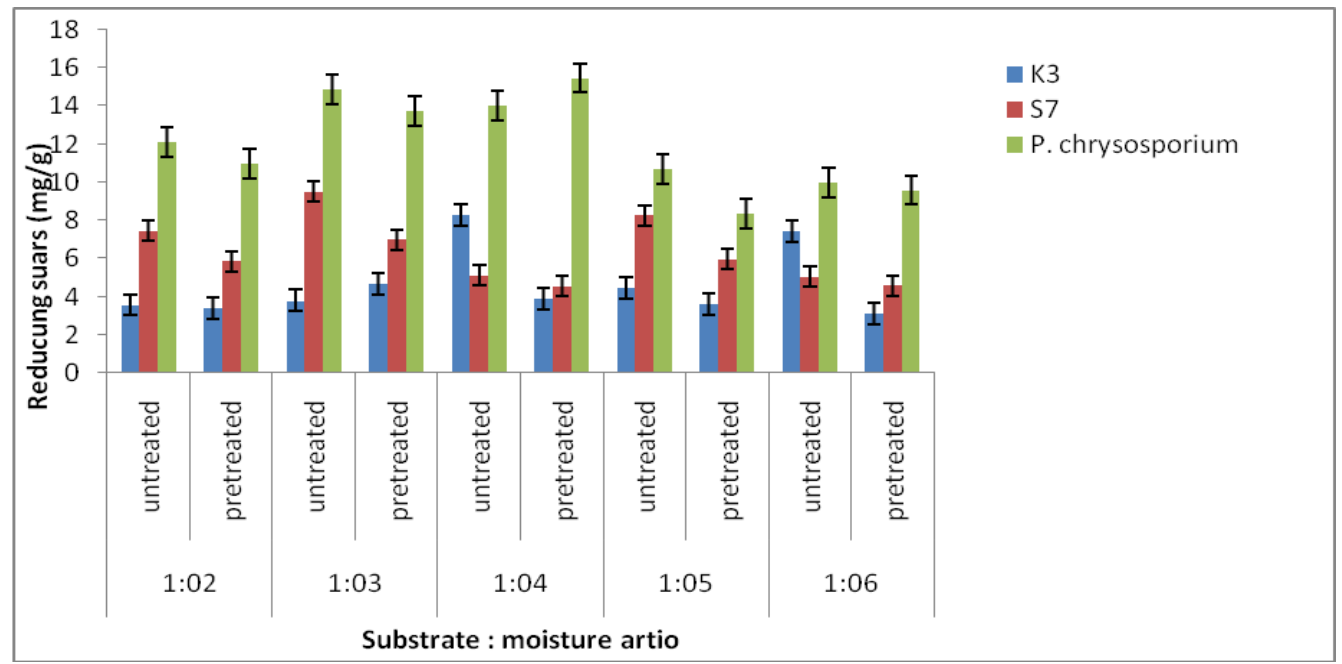


Fig.10 Comparison of laccase production by Armillaria sp. K3, Phanerochaete sp. S7 and $P$. chrysosporium under SSF

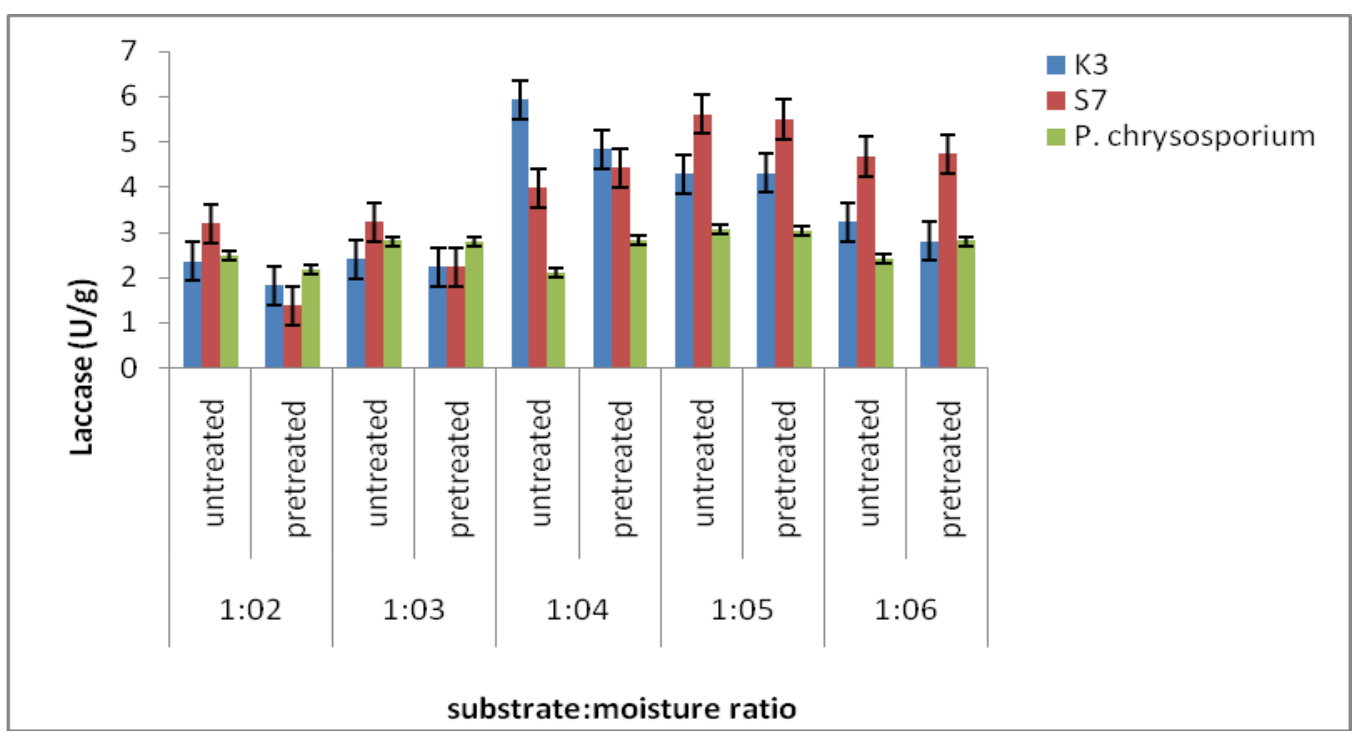

Nair et al., (2008) also reported that Aspergillus spp. were the best xylanase and cellulase producers. Rabah et al., (2010) studied the biodegradation of lignin by whiterot fungi related to the biochemistry of lignocellulose transformation. The ability of white-rot fungi to withstand and degrade tannin is well known (Yague et al., 2000). Trichoderma virescens and $T$. reesii were able to tolerate up to $3000 \mathrm{ppm}$ of pine needle crude tannins without any growth inhibition. However, a much smaller group of filamentous fungi has evolved with the ability to break down lignin, the most recalcitrant component of plant cell walls. These are known as white-rot fungi, brown-rot fungi. Some soft-rot fungi can degrade lignin, because they erode the secondary cell wall and decrease the content of acid-insoluble material (Klason lignin) in angiosperm wood. Soft-rot fungi typically attack higher moisture, and lower lignin content materials (Shary et al., 2008). Crystallinity of biologically pretreated lignocellulosic biomass of Pinus densiflora decreased by using enzymes from brown-rot fungi (Lee et al., 2008). By the analysis of foregoing results and parameters governing the biodegradation process of pine needles by releasing reducing sugars, it can be concluded that pine needles are feasible and has enough potential for bioethanol yield as a green fuel.

\section{Conclusion}

In the present study, the white rot fungi i.e. Armillaria sp. K3, Phanerochaete sp. S7 and $P$. chrysosporium had the potential to utilize lignocellulosic waste such as pine needles as a carbon source to produce valuable enzymes, thus reducing enzyme production cost. These strains also play their role in biological pretreatment as shown in the study, because there is no such observation for maximum enzyme as well as reducing sugar production in microwave pretreated pine needles as compared to untreated pine needles and our newly isolated strains i.e. Armillaria sp. K3 and Phanerochaete sp. S7 were found to be hyper laccase producers (which degrade lignin) as compared to reference strain $P$. chrysosporium. Optimization of moisture ratio is a pre-requisite to enhance the yield under solid state fermentation process which is very helpful in large-scale production. Therefore, being rich in cellulose and 
hemicelluloses, pine needles can serve as a substrate for biodegradation and for the production of useful byproducts like biofuels besides its safe disposal helping to solve the burning issue of global warming and serve as an alternative source for better utilization of environmental waste.

\section{Acknowledgement}

Authors gratefully acknowledge the financial support given by National Mission on Himalayan studies (NMHS), Ministry of Environment, Forest and Climate Change (MoEF\&CC), Govt of India, New Delhi and G.B. Pant National Institute of Himalayan Environment and Sustainable Development (GBPNIHESD), Kosi-Kataramal, Almora, Uttarakhand.

\section{References}

Akpan I. 2004. Screening for novel fungal biocatalysts, A Niger. J Mcrobiol; 18:288-92.

Bakri Y, Jacques O P and Thonart P. 2003. Xylanase production by Penicillium canescens 10-10c in solid state fermentation. Applied Biochemistry and Biotechnology 108: 737-748.

Berghem, L.E.R. and Petterson, L.G. (1973). Mechanism of enzymatic cellulose degradation and purification of a cellulolytic enzyme from $T$. viride active on highly ordered cellulose. J Biochem., 37: 21-30.

Bollag, D.M. and Edelstein, S.J. (1991). Concentrating protein solutions In: Protein methods. A John Wiley Sons, INC, Publications, USA. p.45.

Dalvi, P. and Anthappan, P. (2007). Amylase and pectinase from single source for simultaneous desizing and scouring. Ind J Fiber Text Res., 32: 459-465.

Dias, M.; Dos, S.B.V.; Albuguerque, C.J.B.; Baeta, B.E.L.; Pasquini, D. and Baffi, M.A. (2018). Biomass sorghum as a novel substrate in solid state fermentation for the production of hemicellulases and cellulases by Aspergillus niger and A. fumigates. J. Appl. Microbiol. 124: 708-718.

Dutt D, Kumar A. 2014.Optimization of cellulase production under solid-state fermentation by Aspergillus flavus (at-2) and Aspergillus niger (at-3) and its impact on stickies and ink particle size of sorted office paper. Cellul Chem Technol. 48:285-98.

Ghoshal G, Banerjee UC, Shivhar VS. 2015. Utilization of agrowaste and xylanase production in solid state fermentation. $\mathrm{J}$ Biochem Tech 2015; 6: 1013-24.

Grazek, W. (1987). Comparative studies on the production of cellulases by thermophilic fungi in submerged and solid-state fermentation. Appl Microbiol Biotechnol., 53: 461-68.

Lee, J. W., Kim, H. Y., Koo, B. W., Choi, D. H., Kwon, M. and Choi, I. G., Enzymatic saccharification of biologically pretreated Pinus densiflora using enzymes from brown rot fungi. J. Biosci. Bioeng. Aug., 2008, 106(2), 162-167; doi:10.1263/jbb.106.162.

Lowry, O.H.; Rosebrough, N.J.; Farr, A.L. and Randall, R.J. (1951). Protein measurement with the Folin-phenol reagent. J Biol Chem., 193:265-75.

Miller, G.H. (1959). Use of dinitrosalicylic acid reagent for determination of reducing sugar. Annals Chem., 31:426-29.

Nair Suprabha G, Sandhu R and Shashidhar S. 2008. Fungal xylanase production under solid state and submerged fermentation conditions. African Journal of Microbiology Research 2: 82-86.

Panda SS, Sahoo K, Das R, Dhal NK. Pectinolytic and cellulolytic activity of soil fungal isolates from Similipal Bioreserve forest. World Environ 2012; 2(2):1-3.

Pathania S., Sharma N. and Handa S. 2018. Utilization of horticultural waste (Apple pomace) for multiple carbohydars production from Rhizopus delemar F2 under solid state fermentation. Journal of Genetic Engineering and 
Biotechnology. 16:181-189.

Rabah, A. B., Baki, A. S., Hassan, G., Musa, M. and Ibrahim, A. D., Production of biogas using abattoir waste at different retention time. Sci. World J., 2010, 5(4), 23-26.

Ratan, V.; Dixit S.; Srivastava, M.; Trivedi, S.; Mishra, A.; Srivastava, Y. K. and Srivastava, D. K. (2017). Computational structure prediction and analyze active ligand binding site of defense and lytic enzymes of Trichoderma harzianum. Annal Phytomed., 7: 143-160.

Sharma P., Sharma N and Sharma N. 2019. Scale up and optimization of process parameters for high gravity ethanol fermentation from a fresh water algae Rhizoclonium sp. of Trans Himalayas using Taguchi ortho-gonal array design, kinetics and modeling. Journal of Pharmacogny and Phytochemistry. 8(1); 1386- 1398.

Sharma, N. and Sharma, N. (2016). Enhanced production of cellulase free xylanase from UV irradiated improved strain of Bacillus altitudinis $\mathrm{Kd} 1$ (M) and its scale up in a stirred tank bioreactor. Int J Adv Inf Sci Technol., 45: 127-138

Sharma, N. and Sharma, N. (2017a). Evaluation of different pretreatments for enzymatic digestibility of forest residues and cellulase production by bacillus stratosphericus $\mathrm{n} 12 \quad$ (m) under submerged fermentation. Int $\mathbf{J}$ Curr Res., 9:58430-58436.

Sharma, N. and Sharma, N. (2017b). Microbial xylanases and their industrial applications as well as future perspectives: a review. Global J Biol, Agric Health Sci. 6: 5-12.

Sharma, N. and Sharma, N. (2018). Second generation bioethanol production from lignocellulosic waste and its future perspectives: A review. Int $\mathrm{J}$ Curr Microbiol Appl Sci., 7: 1285-1290.

Shary, S., Ralph, S. A. and Hammel, K. E., New insights into the ligninolytic capability of a wood decay ascomycete. Appl. Environ. Microb., 2007, 73, 6691-6694. 29.

Sohail M, Naseeb S, Sherwani SK, Sultana S, Aftab S, Shahzad S, Ahmad A, Khan SA. Distribution of hydrolytic enzymes among native fungi: Aspergillus the predominant genus of hydrolase producer. Pak J Bot 2009;41: 2567-82.

Thiribhuvanamala, G.; Kalaiselvi, G.; Parthasarathy, S.; Madhavan, S. and Prakasam, V. (2017). Extracellular secretion of lignocellulolytic enzymes by diverse white rot basidiomycetes fungi. Annal Phytomed., 1:20-29.

Yague, S., Terron, M. C., Gonzalez, T., Zapico, E., Bochini, P., Galetti, G. C. and Gonzalez, A. E., Biotreatment of tannin rich beer - factory waste water with white rot basidiomycete Coriolopsis gallica monitored by pyrolyis/gas chromatography/mass spectrometry. Rapid Commun. Mass Sectrom., 2000, 14, 905-910.

\section{How to cite this article:}

Nivedita Sharma, Nisha Sharma and Dimple. 2019. An Evaluation Study of Different White Rot Fungi for Degradation of Pine Needles under Solid State Fermentation. Int.J.Curr.Microbiol.App.Sci. 8(06): 588-601. doi: https://doi.org/10.20546/ijcmas.2019.806.069 